\title{
Crystal structure analysis of the $\mathrm{Ti}_{3} \mathrm{ZrFe}_{2} \mathrm{O}_{0.3} \mathrm{D}_{6.4}$ and $\mathrm{TiZr}_{3} \mathrm{Fe}_{2} \mathrm{O}_{0.3} \mathrm{D}_{7.5}$ deuterides
}

\author{
I.Yu. ZAVALIY ${ }^{1 *}$, R.V. DENYS ${ }^{1,2}$, A.B. RIABOV ${ }^{1}$, I.V. KOVAL'CHUCK ${ }^{1}$, P.Ya. LYUTYY ${ }^{1}$ \\ ${ }^{1}$ Karpenko Physico-Mechanical Institute, National Academy of Sciences of Ukraine, \\ Naukova St. 5, 79601 Lviv, Ukraine \\ ${ }^{2}$ Institute for Energy Technology, P.O. Box 40, NO-2027 Kjeller, Norway \\ * Corresponding author.Tel.: +380-32-2296833; e-mail: zavaliy@ipm.lviv.ua
}

Dedicated to Evgen I. Gladyshevskii (1924-2012)

Received January 8, 2013; accepted June 26, 2014; available on-line November 10, 2014

The crystal structures of two saturated deuterides, $\mathrm{Ti}_{3} \mathrm{ZrFe}_{2} \mathrm{O}_{0.3} \mathrm{D}_{6.4}$ and $\mathrm{TiZr}_{3} \mathrm{Fe}_{2} \mathrm{O}_{0.3} \mathrm{D}_{7.5}$, have been investigated by both $\mathrm{X}$-ray and neutron powder diffraction. Hydrogenation of these oxygen-stabilized $\eta$-phases with $\mathrm{Ti}_{2} \mathrm{Ni}$-type structure proceeds through expansion of their unit cells by 15.5 and $17.3 \%$, respectively, without change of the type of metal matrix. In both cases deuterium atoms fill tetrahedral interstices D2 (192i) and D3 $(96 \mathrm{~g})$ with $(\mathrm{Ti}, \mathrm{Zr})_{3} \mathrm{Fe}$ surrounding, and T2 (32e) triangular interstices with $(\mathrm{Ti}, \mathrm{Zr})_{3}$ surrounding. In the case of $\mathrm{Ti}_{3} \mathrm{ZrFe}_{2} \mathrm{O}_{0.3}$ the octahedral interstice $\mathrm{D7}(8 \mathrm{a})$ with $(\mathrm{Ti}, \mathrm{Zr})_{6}$ surrounding is filled as well, whereas in the case of $\mathrm{TiZr}_{3} \mathrm{Fe}_{2} \mathrm{O}_{0.3}$ the triangular interstice $\mathrm{T1}(32 e)$ with $(\mathrm{Ti}, \mathrm{Zr})_{3}$ surrounding is filled as well. The insertion of deuterium atoms into the metal matrix of $\eta-T_{i Z} r_{3} F_{2} O_{0.3}$ induces partial transfer of oxygen atoms from 01 (16c) octahedra into D7 (8a) octahedra.

Titanium and zirconium alloys / Metal hydrides / Crystal structure / X-ray diffraction / Powder neutron diffraction

\section{Introduction}

Ti-Fe-based alloys are among the easiest available hydrogen storage materials. The intermetallic compound $\mathrm{TiFe}(\mathrm{CsCl}$ structure type) absorbs hydrogen up to the composition $\mathrm{TiFeH}_{1.1}$ at ambient pressure, and to $\mathrm{TiFeH}_{1.94}$ under elevated hydrogen pressures [1-3]. This compound can also dissolve significant amounts of oxygen, with the formation of the $\eta$-phase $\mathrm{Ti}_{4-x} \mathrm{Fe}_{2+x} \mathrm{O}_{y}$, which adopts the $\mathrm{Ti}_{2} \mathrm{Ni}$ $\left(\eta-\mathrm{Fe}_{3} \mathrm{~W}_{3} \mathrm{C}\right)$ structure type. The phase is characterized by variable $\mathrm{Ti} / \mathrm{Fe}$ composition (from $2: 1$ to $1: 1$ ) and an oxygen concentration of up to 14 at.\% [4]. Oxygenmodified Ti-Fe alloys exhibit improved hydrogenation activation parameters, compared to oxygen-free alloys, and can be considered as less expensive hydrogen storage materials [4].

The $\mathrm{Zr}-\mathrm{Fe}$ binary system is characterized by the formation at high temperature $\left(775-974{ }^{\circ} \mathrm{C}\right)$ of the $\mathrm{Zr}_{2} \mathrm{Fe}$ compound, which crystallizes in the tetragonal $\mathrm{CuAl}_{2}$ structure type. Stabilized by oxygen, the $\eta$-phase $\mathrm{Zr}_{4} \mathrm{Fe}_{2} \mathrm{O}_{x}$ crystallizes in the cubic $\mathrm{Ti}_{2} \mathrm{Ni}$ $\left(\eta-\mathrm{Fe}_{3} \mathrm{~W}_{3} \mathrm{C}\right)$ structure type. The lower $(x=0.25)$ and upper $(x=0.6)$ limits of the oxygen concentration in the $\eta$-phase $\mathrm{Zr}_{4} \mathrm{Fe}_{2} \mathrm{O}_{x}$ were established by means of $\mathrm{X}$-ray structure investigations $[5,6]$. It was shown that the hydrogenation capacity of the $\mathrm{Zr}_{4} \mathrm{Fe}_{2} \mathrm{O}_{x}$ alloys depends on the oxygen content (from $9.9 \mathrm{H} / \mathrm{f}$.u. for $x=0.25$ to 5.4 for $x=0.6$ ) [7]. A comparison of the hydrogenation of the $\mathrm{Zr}_{2} \mathrm{Fe}$ and $\mathrm{Zr}_{4} \mathrm{Fe}_{2} \mathrm{O}_{x}$ compounds showed that the $\mathrm{O}$-containing phases are more stable against hydrogen disproportionation at elevated temperatures [8]. Both $\mathrm{Zr}_{2} \mathrm{Fe}$ and $\mathrm{Zr}_{4} \mathrm{Fe}_{2} \mathrm{O}_{x}$ alloys are efficient absorbers of hydrogen and other active gases at low pressures.

The existence of a continuous solid solution in the $\mathrm{Ti}_{4} \mathrm{Fe}_{2} \mathrm{O}_{x}-\mathrm{Zr}_{4} \mathrm{Fe}_{2} \mathrm{O}_{x} \quad(0.25 \leq x \leq 0.5) \quad$ system was established by means of X-ray phase analysis [9]. The hydrogenation properties, as well as the crystal structures of the $\mathrm{Ti}_{4} \mathrm{Fe}_{2} \mathrm{O}_{x}$ and $\mathrm{Ti}_{2} \mathrm{Zr}_{2} \mathrm{Fe}_{2} \mathrm{O}_{x}$ hydrides, were also studied [9]. The authors showed that $\left(\mathrm{Ti}_{1-x} \mathrm{Zr}_{x}\right)_{4} \mathrm{Fe}_{2} \mathrm{O}_{y}$ alloys absorb significant amounts of hydrogen (from 0.6 to $1.7 \mathrm{H}$ atoms per metal atom). During hydrogenation the metal matrix of the compounds preserves the cubic structure $\left(\eta-\mathrm{Fe}_{3} \mathrm{~W}_{3} \mathrm{C}\right.$ structure type) and the unit cell expansion is 9.5-17.3\%. It was shown that the hydrogen capacity decreases with increasing O-content and rises when $\mathrm{Ti}$ is replaced by $\mathrm{Zr}$.

The results of crystal structure investigations of two deuterides of this series, namely $\mathrm{Ti}_{3} \mathrm{ZrFe}_{2} \mathrm{O}_{x} \mathrm{D}_{6.4}$ and $\mathrm{TiZr}_{3} \mathrm{Fe}_{2} \mathrm{O}_{x} \mathrm{D}_{7.3}$, are presented in this paper. 


\section{Experimental details}

$\mathrm{Ti}_{3} \mathrm{ZrFe}_{2} \mathrm{O}_{x}$ and $\mathrm{TiZr}_{3} \mathrm{Fe}_{2} \mathrm{O}_{x}$ alloys were prepared from high-purity compact metals $(\geq 99.9 \%)$ and compacted powders of $\mathrm{TiO}_{2}$ or $\mathrm{ZrO}_{2}$ oxide by arc melting in purified argon. The as-cast alloys were annealed in vacuum at $980^{\circ} \mathrm{C}$ for 5 days. Hydrogenation was performed at room temperature in an autoclave under 0.1-0.15 $\mathrm{MPa}$ hydrogen pressure, after preliminary activation of the samples by heating at $500{ }^{\circ} \mathrm{C}$ for $15 \mathrm{~min}$. The amount of absorbed hydrogen was measured volumetrically.

Phase-structural analysis of the alloys and their hydrides (deuterides) was performed on XRD data collected on a DRON-3.0 $(\mathrm{Cu} K \alpha)$ diffractometer. The structures of the deuterides were studied by powder neutron diffraction, on data collected at the Neutron Research Laboratory of Uppsala University (Studsvik, Sweden) with the use of NPD $(\lambda=1.47 \AA)$ and R2D2 $(\lambda=1.55 \AA)$ diffractometers. The structures were refined by full-profile Rietveld analysis, using CSD and GSAS programs $[10,11]$.

\section{Results and discussion}

Synthesis of deuterides and some general approaches to a description of the studied structures

Deuterides of the $\eta$-phases $\mathrm{Ti}_{3} \mathrm{ZrFe}_{2} \mathrm{O}_{0.3}$ and $\mathrm{TiZr}_{3} \mathrm{Fe}_{2} \mathrm{O}_{0.3}$ were prepared at room temperature at $0.15 \mathrm{MPa}$ final hydrogen pressure. The hydrogenation capacity was calculated from pressure changes at constant volume and reached $6.4 \mathrm{D} / \mathrm{f}$.u. for $\mathrm{Ti}_{3} \mathrm{ZrFe}_{2} \mathrm{O}_{0.3}$ and $7.3 \mathrm{D} / \mathrm{f}$.u. for $\mathrm{TiZr}_{3} \mathrm{Fe}_{2} \mathrm{O}_{0.3}$. The crystal structures of the synthesized deuterides were studied by X-ray powder and neutron diffraction. The hydrogen and oxygen atomic positions in the metal sublattice of the $\mathrm{Ti}_{3} \mathrm{ZrFe}_{2} \mathrm{O}_{0.3} \mathrm{D}_{6.4}$ and $\mathrm{Ti}_{3} \mathrm{ZrFe}_{2} \mathrm{O}_{0.3} \mathrm{D}_{7.3}$ deuterides were established by Rietveld refinement.

The description of the interstices (D1-D8) proposed by Westlake [12] for $\mathrm{Ti}_{2} \mathrm{Ni}$-structure types deuterides was used in our previous [9] and this work for the structural analysis of $(\mathrm{Ti}, \mathrm{Zr})_{4} \mathrm{Fe}_{2} \mathrm{O}_{x} \mathrm{D}_{y}$. Calculation of the radii of the interstices showed that hydrogen atoms can fill tetrahedral $[M 3 \mathrm{Fe}]-\mathrm{D} 1$ (32e), D2 (192i) and D3 (96g) - as well as octahedral [M6] - D7 (8a) - interstices. Other types of interstice, namely tetrahedral [M2Fe2] (D4), [MFe3] (D6) and [Fe4] (D5), are not favorable for the insertion of hydrogen atoms. The sizes of the interstices depend on the level of $\mathrm{Zr}$ substitution for Ti. D2 and D3, the most occupied sites in the studied hydrides, have the radii $r_{\text {int }}=0.35 \AA$ and $r_{\text {int }}=0.36 \AA$ in the Ti-based alloys. In the Zr-based alloys $r_{\text {int }}=0.42-0.44 \AA$ and $r_{\text {int }}=0.46-0.48 \AA$. The structure of the hydrogen sublattice in the studied oxygen-stabilized $\eta$-phases obeys the principles of the crystal chemistry of metal hydrides: a) the radii of occupied interstices $>0.40 \AA$; b) all H-H distances are at least $2.0 \AA$; c) interstices formed by active hydrogen-forming metals ( $\mathrm{Ti}, \mathrm{Zr}$ ) are filled in the first turn. It should to be noted that $\mathrm{O}-\mathrm{H}$ blocking has a strong impact.

The types of interstice in the $(\mathrm{Ti}, \mathrm{Zr})_{4} \mathrm{Fe}_{2} \mathrm{O}_{x}$ structure are represented in Fig. 1. Moreover, filling of the triangular $\mathrm{T} 1$ and $\mathrm{T} 2$ faces $\left[M 1_{3}\right]$ (discussed below), between the D7/D8 and D7/D1 interstices was detected. Such filling is also typical for $\mathrm{Hf}_{2} \mathrm{Fe}$, $\mathrm{Zr}_{3} \mathrm{~V}_{3} \mathrm{O}_{x}$ and $\mathrm{Ti}_{2} \mathrm{Zr}_{2} \mathrm{Fe}_{2} \mathrm{O}_{x} \mathrm{D}_{y}$ deuterides $[9,13,14]$.

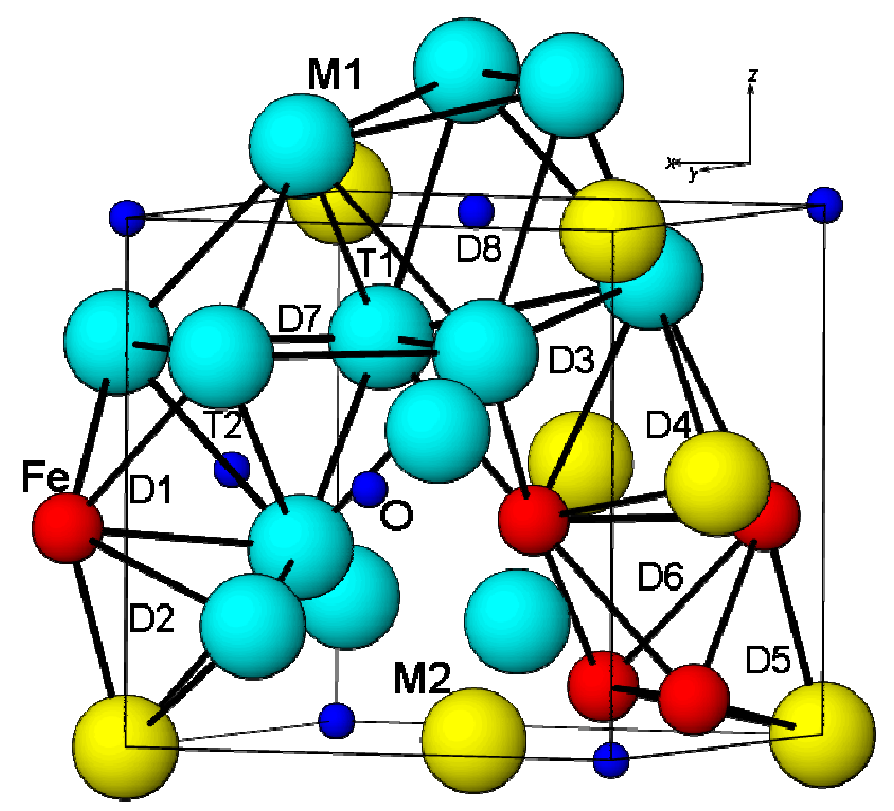

Fig. 1 Types of interstice (D1-D8 and O) in the (Ti, $\mathrm{Zr})_{4} \mathrm{Fe}_{2} \mathrm{O}_{x}$ structure, shown for $1 / 8$ unit cell. 
I.Yu. Zavaliy et al., Crystal structure analysis of the $\mathrm{Ti}_{3} \mathrm{ZrFe}_{2} \mathrm{O}_{0.3} \mathrm{D}_{6.4}$ and $\mathrm{TiZr}_{3} \mathrm{Fe}_{2} \mathrm{O}_{0.3} \mathrm{D}_{7.5}$ deuterides
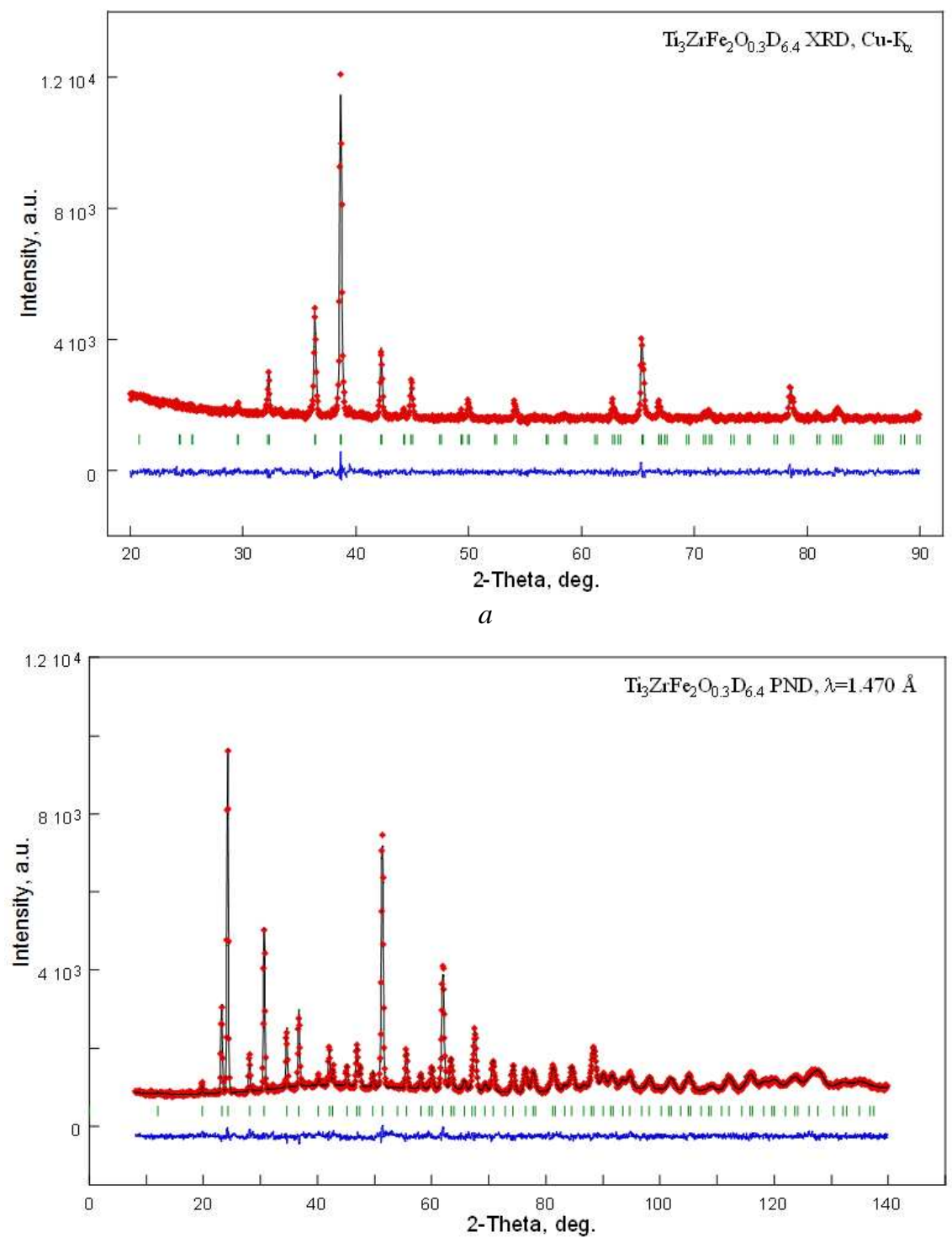

b

Fig. 2 Observed $(\bullet$, calculated (line) and difference (bottom line) Rietveld profiles for X-ray powder diffraction $(a)$ and neutron powder diffraction $(b)$ of the $\mathrm{Ti}_{3} \mathrm{ZrFe}_{2} \mathrm{O}_{0.3} \mathrm{D}_{6.4}$ deuteride.

Table 1 Crystallographic data for $\mathrm{Ti}_{3} \mathrm{ZrFe}_{2} \mathrm{O}_{0.3} \mathrm{D}_{6.4}$ (space group $F d-3 m ; a=12.1185(1) \AA$; $\mathrm{R}_{\mathrm{p}}=2.84 \%$, $\mathrm{R}_{\mathrm{wp}}=3.26 \%, \chi^{2}=1.57$; refined composition: $\left.\mathrm{Ti}_{3.01} \mathrm{Zr}_{0.99} \mathrm{Fe}_{2} \mathrm{O}_{0.25} \mathrm{D}_{6.4}\right)$.

\begin{tabular}{|c|c|c|c|c|c|c|c|}
\hline Atom & Site & $x$ & $y$ & $z$ & $U_{\text {iso }} \times 100, \AA^{2}$ & SOF & $r_{\text {int }}, \stackrel{\AA}{A}$ \\
\hline$M 1$ & $48 f$ & $0.3157(4)$ & $1 / 8$ & $1 / 8$ & $1.3(2)$ & $0.681(4) \mathrm{Ti} / 0.319(4) \mathrm{Zr}$ & \\
\hline$M 2$ & $16 d$ & $1 / 2$ & $1 / 2$ & $1 / 2$ & $1.8(2)$ & $0.963(6) \mathrm{Ti} / 0.037(6) \mathrm{Zr}$ & \\
\hline $\mathrm{Fe}$ & $32 e$ & $0.70231(8)$ & $0.70231(8)$ & $0.70231(8)$ & $1.02(4)$ & $1.0(-)$ & \\
\hline $\mathrm{O}$ & $16 c$ & 0 & 0 & 0 & $1.5(6)$ & $0.25(1)$ & 0.78 \\
\hline $\mathrm{T} 2$ & $32 e$ & $0.069(1)$ & $0.069(1)$ & $0.069(1)$ & $3.4(9)$ & $0.16(1)$ & 0.38 \\
\hline D2 & $192 i$ & $0.4810(7)$ & $0.5679(7)$ & $0.3584(8)$ & $0.015(4)$ & $0.114(5)$ & 0.41 \\
\hline D3 & $96 g$ & $0.2817(2)$ & $0.2817(2)$ & $0.1546(2)$ & $0.025(1)$ & $0.718(9)$ & 0.46 \\
\hline D7 & $8 a$ & $1 / 8$ & $1 / 8$ & $1 / 8$ & $0.052(7)$ & $0.72(3)$ & 0.80 \\
\hline
\end{tabular}




\section{Structure of the $\mathrm{Ti}_{3} \mathrm{ZrFe}_{2} \mathrm{O}_{0.3} \mathrm{D}_{6.4}$ deuteride}

Graphical representations of the full-profile Rietveld refinements of the $\mathrm{X}$-ray and neutron diffraction patterns of $\mathrm{Ti}_{3} \mathrm{ZrFe}_{2} \mathrm{O}_{0.3} \mathrm{D}_{6.4}$ are shown in Fig. 2 ( $a$ and $b$, respectively).

The results of the joint X-ray and neutron structure refinement are given in Table 1. The degree of $\mathrm{Zr}$ substitution on the $M$ positions was determined. The M1 position is filled by $68.1 \% \mathrm{Ti}$ and $31.9 \% \mathrm{Zr}$ atoms and the $M 2$ position is filled by $96.3 \% \mathrm{Ti}$ and $3.7 \% \mathrm{Zr}$ atoms. The oxygen content is $0.25 \mathrm{O} / \mathrm{f}$.u. The hydrogen content is in good agreement with the volumetric data. In addition to D3 and D7 (see under 3.1), hydrogen atoms also fill $\mathrm{D} 2$ and triangular $\mathrm{T} 2$ faces. Due to D3-D2 blocking effect and D2-D2 selfblocking, the D2 position can be filled by $14 \%$, and is filled by $11.4 \%$. Only $16 \%$ of the possible $21 \%$ (limited due to T2-O1 and T2-D7 blocking) of the T2 positions are filled. It was also shown that filling of D7 $\left(r_{\text {int }}=0.8 \AA, \mathrm{SOF}=0.72\right)$ positions occurs. The size of D7 significantly exceeds the size of the other filled interstices (T2, D2, D3) with radii from 0.38 to $0.46 \AA$.

\section{Structure of the $\mathrm{TiZr}_{3} \mathrm{Fe}_{2} \mathrm{O}_{0.3} \mathrm{D}_{7.5}$ deuteride}

Experimental $\mathrm{X}$-ray and neutron diffraction profiles for the $\mathrm{TiZr}_{3} \mathrm{Fe}_{2} \mathrm{O}_{0.3} \mathrm{D}_{7.3}$ deuteride are presented in Fig. 3 ( $a$ and $b$, respectively). Parameters of the crystal structure of the $\mathrm{TiZr}_{3} \mathrm{Fe}_{2} \mathrm{O}_{0.3} \mathrm{D}_{7.3}$ deuteride, obtained by joint Rietveld refinement of XRD and PND data, are provided in Table 2. As follows from the joint refinement of the structure, the $M 1$ position is filled by 95.5 \% $\mathrm{Zr}$ and $4.5 \% \mathrm{Ti}$ atoms, and the $M 2$ position is filled by $87.0 \% \mathrm{Ti}$ and $13.0 \% \mathrm{Zr}$ atoms.

The radii of the interstices were calculated considering that the $M 1$ position is filled by $\mathrm{Zr}$ atoms,

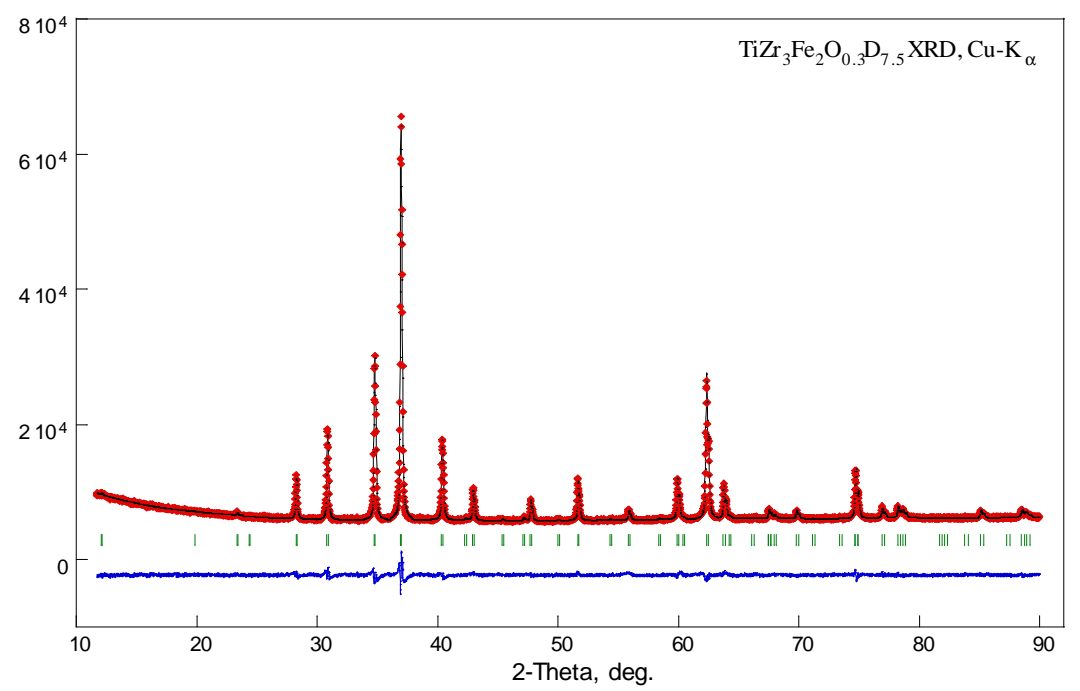

$a$

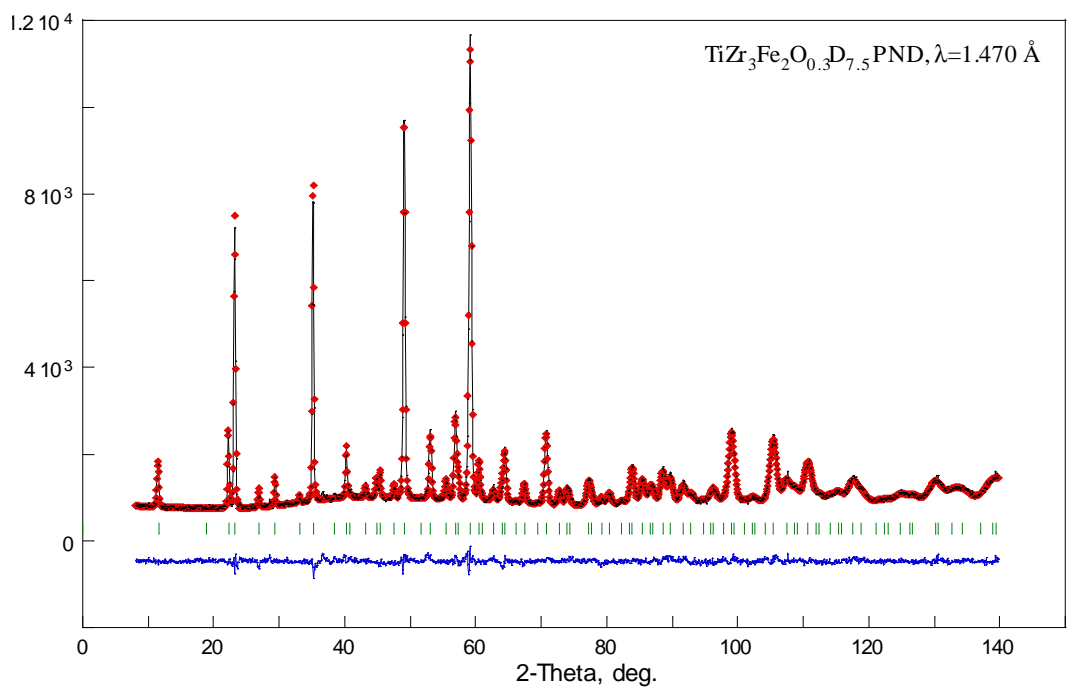

b

Fig. 3 Observed (points), calculated (line) and differential (lower line) profiles for X-ray powder diffraction (a) and neutron powder diffraction $(b)$ of the $\mathrm{TiZr}_{3} \mathrm{Fe}_{2} \mathrm{O}_{0.3} \mathrm{D}_{7.5}$ deuteride. 
Table 2 Crystallographic data for $\mathrm{TiZr}_{3} \mathrm{Fe}_{2} \mathrm{O}_{0.3} \mathrm{D}_{7.5}$ (space group $F d-3 m ; a=12.6349(2) \AA ; \mathrm{R}_{\mathrm{p}}=3.04 \%$, $\mathrm{R}_{\mathrm{wp}}=3.98 \%, \chi^{2}=3.1$; refined composition: $\left.\mathrm{Ti}_{1.00} \mathrm{Zr}_{3.00} \mathrm{Fe}_{2} \mathrm{O}_{0.31} \mathrm{D}_{7.3}\right)$.

\begin{tabular}{|c|c|c|c|c|c|c|c|}
\hline Atom & Site & $x$ & $y$ & $z$ & $U_{\text {iso }} \times 100, \AA^{2}$ & SOF & $r_{\text {int }}, \AA$ \\
\hline$M 1$ & $48 f$ & $0.31576(9)$ & $1 / 8$ & $1 / 8$ & $1.28(4)$ & $0.045(7) \mathrm{Ti} / 0.955(7) \mathrm{Zr}$ & \\
\hline$M 2$ & $16 d$ & $1 / 2$ & $1 / 2$ & $1 / 2$ & $0.20(1)$ & $0.870(5) \mathrm{Ti} / 0.130(5) \mathrm{Zr}$ & \\
\hline $\mathrm{Fe}$ & $32 e$ & $0.69912(7)$ & $0.69912(7)$ & $0.69912(7)$ & $1.77(6)$ & $1.0(-)$ & \\
\hline $\mathrm{O} 1$ & $16 c$ & 0 & 0 & 0 & $1.0(-)$ & $0.14(1)$ & 0.78 \\
\hline $\mathrm{T} 1$ & $32 e$ & $0.186(2)$ & $0.186(2)$ & $0.186(2)$ & $2.3(3)$ & $0.084(8)$ & 0.37 \\
\hline $\mathrm{T} 2$ & $32 e$ & $0.0630(3)$ & $0.0630(3)$ & $0.0630(3)$ & $2.3(3)$ & $0.53(1)$ & 0.37 \\
\hline D2 & $192 i$ & $0.4814(6)$ & $0.5683(6)$ & $0.3642(6)$ & $1.8(3)$ & $0.184(7)$ & 0.44 \\
\hline D3 & $96 g$ & $0.2833(2)$ & $0.2833(2)$ & $0.1577(3)$ & $1.8(1)$ & $0.64(1)$ & 0.48 \\
\hline$D 7^{a}$ & $8 a$ & $1 / 8$ & $1 / 8$ & $1 / 8$ & $1.0(-)$ & $0.32(2) 0$ & 0.81 \\
\hline
\end{tabular}

${ }^{\mathrm{a}}$ Position D7 is occupied by oxygen.

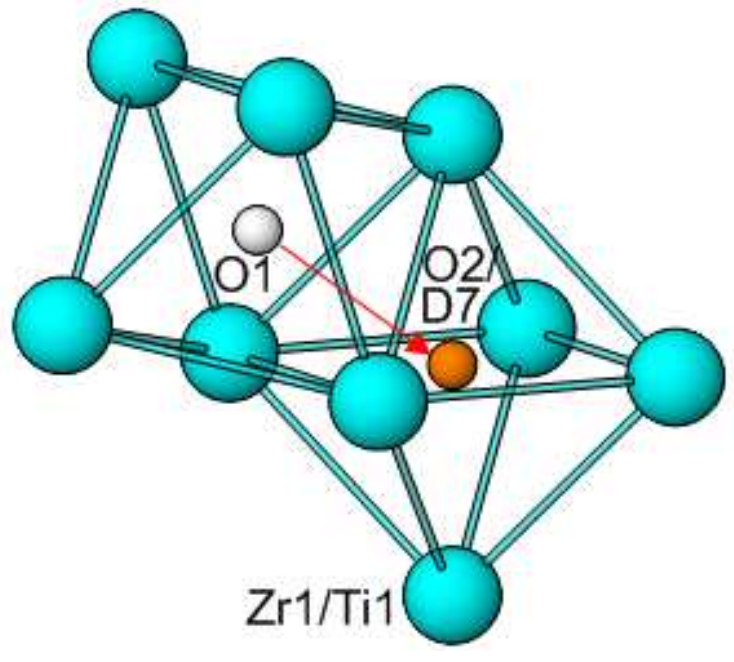

Fig. 4 Octahedra $(\mathrm{Zr} 1 / \mathrm{Ti} 1)_{6}$ centered by $\mathrm{O} 1$ and $\mathrm{O} 2$ (D7).

and the $M 2$ position is filled by Ti atoms. Refinement of the crystal structure revealed redistribution of the oxygen atoms upon hydrogenation. We have already observed a similar situation in the case of $\mathrm{O}$-stabilized $\mathrm{Zr}_{3} M \mathrm{O}_{x}$ compounds $(M=\mathrm{Fe}, \mathrm{Co}, \mathrm{Ni}) \quad[15]$. Hydrogenation induces partial transfer of oxygen atoms from O1 (16c) octahedra into D7 (8a) octahedra (Fig. 4). Taking into account the blocking effect when 1 D3 (multiplicity 96) blocks 2 D2 (192), this means that $1 / 96 \mathrm{O} 1$ of the unit cell blocks $2 / 192 \mathrm{~T} 2$ positions. In the case of absence of self-blocking between $\mathrm{T} 2$ triangles we can assume filling of 30/32 interstices. Since oxygen atoms fill position $\mathrm{O} 1$ by $14 \%$, the T2 position can be filled by hydrogen atoms to $86 \%$. On the other hand, taking into account the blocking $\mathrm{O} 2(8 a)-\mathrm{T} 2$, this means that $1 / 8 \mathrm{O} 2$ blocks $4 / 32 \mathrm{~T} 2$, therefore, for a degree of filling of $\mathrm{O} 2$ of $32 \%$, T2 can be filled to $68 \%$. Summing up the effect of oxygen blocking of the triangular faces $\mathrm{T} 2$ in $\mathrm{TiZr}_{3} \mathrm{Fe}_{2} \mathrm{O}_{0.3} \mathrm{D}_{7.3}$, the maximum occupancy is $0.68 \times 0.86 \times 100 \%=$
$58.5 \%$ (experimental value $53 \%$ ). Because of $\mathrm{T} 2-\mathrm{T} 1$ blocking, interstices $\mathrm{T} 1$ are only filled in the case when the closest $\mathrm{T} 2$ interstices are blocked by $\mathrm{O} 1$ atoms from neighboring octahedra. Therefore, filling of T1 interstices (taking into account O1-T2 blocking) proceeds only to $8 \%$ (from $15 \%$ possible). The distribution of the hydrogen atoms over the interstices in structures on the basis of $\eta-\mathrm{Ti}_{4-x} \mathrm{Zr}_{x} \mathrm{Fe}_{2} \mathrm{O}_{y}$ (with an oxygen content of $y=0.25-0.3$ ) is provided in Table 3 .

The hydrogen sublattice of the studied hydrides, similarly to earlier described hydrides of $\eta$-phases, is not ordered. The reason for this is in the partial filling of oxygen positions in octahedra. Because of repulsion between hydrogen atoms ( $\mathrm{H}-\mathrm{H}$ blocking effect) and between oxygen and hydrogen atoms (O-H blocking), the rest of the interstices are partially filled as well. A decrease of the oxygen content in the compounds, and consequently of the degree of filling of the octahedral interstices, leads to a rise of the number of interstices available for hydrogen atoms. In Table 3, a comparison of the hydrogen distribution over the interstices in $\mathrm{Ti}_{4-x} \mathrm{Zr}_{x} \mathrm{Fe}_{2} \mathrm{O}_{0.25-0.3}$ hydrides, including data for $\mathrm{Zr}_{4} \mathrm{Fe}_{2} \mathrm{O}_{0.25}$, is presented. It follows from the results of a refinement that the structure of the metal sublattice in the $\mathrm{Zr}_{4} \mathrm{Fe}_{2} \mathrm{O}_{0.25}$ hydride is deformed. A detailed description of the structure of this compound will be published elsewhere.

\section{Conclusions}

The hydrogenation parameters of the $\eta$-phases $(\mathrm{Ti}, \mathrm{Zr})_{4} \mathrm{Fe}_{2} \mathrm{O}_{x}$ depend on the $\mathrm{Ti} / \mathrm{Zr}$ ratio, as well as on the oxygen content. The substantial changes of the equilibrium dissociation pressure observed for these alloys mean that titanium alloys can be efficient materials for hydrogen storage systems, whereas zirconium alloys are getters of hydrogen and other active gases. The structure of the hydrogen sublattice of $\eta-(\mathrm{Ti}, \mathrm{Zr})_{4} \mathrm{Fe}_{2} \mathrm{O}_{x}$ also depends on the $\mathrm{Ti} / \mathrm{Zr}$ ratio and the amount of oxygen.

Hydrogenation of the $\mathrm{Ti}_{3} \mathrm{ZrFe}_{2} \mathrm{O}_{0.3}$ and $\mathrm{TiZr}_{3} \mathrm{Fe}_{2} \mathrm{O}_{0.3} \eta$-phases proceeds through expansion of their unit cells by 15.5 and $17.3 \%$, respectively, 
I.Yu. Zavaliy et al., Crystal structure analysis of the $\mathrm{Ti}_{3} \mathrm{ZrFe}_{2} \mathrm{O}_{0.3} \mathrm{D}_{6.4}$ and $\mathrm{TiZr}_{3} \mathrm{Fe}_{2} \mathrm{O}_{0.3} \mathrm{D}_{7.5}$ deuterides

Table 3 Distribution of hydrogen atoms in the structures of hydrides on the basis of $\eta-\mathrm{Ti}_{4-x} \mathrm{Zr}_{x} \mathrm{Fe}_{2} \mathrm{O}_{y}$.

\begin{tabular}{|c|c|c|c|c|c|c|}
\hline \multirow{2}{*}{$\begin{array}{c}\text { Filled } \\
\text { interstice }\end{array}$} & \multirow{2}{*}{ Surrounding } & \multicolumn{5}{|c|}{ Number of hydrogen atoms per unit cell } \\
\hline & & $\mathrm{Ti}_{4} \mathrm{Fe}_{2} \mathrm{O}_{0.25} \mathrm{D}_{4.9}$ & $\mathrm{Ti}_{3} \mathrm{ZrFe}_{2} \mathrm{O}_{0.3} \mathrm{D}_{6.4}$ & $\mathrm{Ti}_{2} \mathrm{Zr}_{2} \mathrm{Fe}_{2} \mathrm{O}_{0.25} \mathrm{D}_{6.8}$ & $\mathrm{TiZr}_{3} \mathrm{Fe}_{2} \mathrm{O}_{0.3} \mathrm{D}_{7.3}$ & $\mathrm{Zr}_{4} \mathrm{Fe}_{2} \mathrm{O}_{0.25} \mathrm{D}_{9.9}$ \\
\hline $\mathrm{D} 1(32 e)$ & $(\mathrm{Ti}, \mathrm{Zr})_{3} \mathrm{Fe}$ & - & - & - & - & 22.11 \\
\hline $\mathrm{T} 1(32 e)$ & $(\mathrm{Ti}, \mathrm{Zr})_{3}$ & - & - & 1.12 & 16.96 & 6.46 \\
\hline $\mathrm{T} 2(32 e)$ & $(\mathrm{Ti}, \mathrm{Zr})_{3}$ & - & 5.12 & 8.51 & 2.69 & - \\
\hline D2 (192i) & $(\mathrm{Ti}, \mathrm{Zr})_{3} \mathrm{Fe}$ & 7.30 & 21.89 & 41.66 & 35.33 & 49.92 \\
\hline D3 $(96 g)$ & $(\mathrm{Ti}, \mathrm{Zr})_{3} \mathrm{Fe}$ & 62.59 & 68.93 & 54.34 & 61.44 & 45.02 \\
\hline D4 $(96 g)$ & $(\mathrm{Ti}, \mathrm{Zr})_{2} \mathrm{Fe}_{2}$ & - & - & - & - & 6.86 \\
\hline D5 (8b) & $\mathrm{Fe}_{4}$ & - & - & - & - & 2.08 \\
\hline D6 $(32 e)$ & $(\mathrm{Ti}, \mathrm{Zr}) \mathrm{Fe}_{3}$ & - & - & - & - & - \\
\hline D7 $(8 a)$ & $(\mathrm{Ti}, \mathrm{Zr})_{6}$ & 8 & 5.76 & 2.83 & - & - \\
\hline D8 $(16 c)$ & $(\mathrm{Ti}, \mathrm{Zr})_{6}$ & - & - & - & - & - \\
\hline \multicolumn{2}{|c|}{$\begin{array}{c}\text { Total amount of } \\
\text { hydrogen }\end{array}$} & 77,89 & 101.70 & 108.46 & 116.42 & 132.45 \\
\hline
\end{tabular}

without change of the type of metal matrix. Deuterium atoms fill in both cases tetrahedral interstices D2 (192i) and D3 (96g) with $(\mathrm{Ti}, \mathrm{Zr})_{3} \mathrm{Fe}$ surrounding and T2 (32e) triangular interstices with $(\mathrm{Ti}, \mathrm{Zr})_{3}$ surrounding. In the case of $\mathrm{Ti}_{3} \mathrm{ZrFe}_{2} \mathrm{O}_{0.3}$, the octahedral interstice D7 $(8 a)$ with $(\mathrm{Ti}, \mathrm{Zr})_{6}$ surrounding is filled as well, whereas in the case of $\mathrm{TiZr}_{3} \mathrm{Fe}_{2} \mathrm{O}_{0.3}$, the triangular interstice $\mathrm{T} 1 \quad(32 e)$ with $(\mathrm{Ti}, \mathrm{Zr})_{3}$ surrounding is filled as well. Refinement of the crystal structure also revealed redistribution of oxygen atoms upon hydrogenation. Insertion of hydrogen (deuterium) atoms into the metal matrix of the $\eta$-phase of composition $\mathrm{TiZr}_{3} \mathrm{Fe}_{2} \mathrm{O}_{0.3}$ induced partial transfer of oxygen atoms from $\mathrm{O} 1(16 c)$ octahedra into D7 (8a) octahedra.

\section{References}

[1] E.K. Molchanova, Atlas of Phase Diagrams of Titanium Alloys, Mashinostroyenie, Moscow, 1964, 390 p. (in Russian).

[2] T. Nambu, H. Ezaki, H. Yukawa, M. Morinaga, J. Alloys Compd. 293-295 (1999) 213-216.

[3] P. Fischer, J. Schefer, K. Yvon, L. Schlapbach, T. Riesterer, J. Less-Common Met. 129 (1987) 39-45.

[4] B. Rupp, J. Less-Common Met. 104 (1984) 51-63.

[5] D. Arias, J.P. Abriata, The Fe-Zr System, In: T.B. Massalski (Ed.), Binary Alloy Phase Diagrams, 2nd Edition, ASM International, Materials Park, Ohio, 1990, Vol. 2, pp. $1798-1800$.
[6] M.V. Nevitt, W. Downey, A. Morris, Trans. Met. Soc. AIME 218 (1960) 1019.

[7] I.Yu. Zavaliy, A.O. Pecharsky, R. Cerny, P.Yu. Zavalij, W.B. Yelon, G. Wiesinger, V.K. Pecharsky, Proc. 20th Eur. Crystallogr. Meet. (ECM'2001), Cracow, Poland, 2001, p. 304. (S8.M1.P17).

[8] I.Yu. Zavaliy, O. Gutfleisch, V.A. Yartys, I.R. Harris, Proc. VII Int. Conf. Hydrogen Materials, Science and Chemistry of Metal Hydrides, Alushta, Kiev, Ukraine, 2001, pp. 336-339.

[9] I.Yu. Zavaliy, R.V. Denys, I.V. Koval'chuck, A.B. Riabov, R.G. Delaplane, Chem. Met. Alloys 2 (2009) 59-67.

[10] L.G. Akselrud, Yu.N. Grin, P.Yu. Zavalii, V.K. Pecharsky, V.S. Fundamensky, Coll. Abstr. 12th Eur. Crystallogr. Meet., Moscow, 1989, Vol. 3, p. 155.

[11] A.C. Larson, R.B. von Dreele, General Structure Analysis System, LANL, Los Alamos, USA, 1994.

[12] D.G. Westlake, J. Less-Common Met. 105 (1985) 69-81.

[13] J. Soubeyroux, D. Fruchart, S. Gerdour, P. Vuillet, A. Roualt, J. Less-Common Met. 129 (1987) 187-195.

[14] I.Yu. Zavaliy, W.B. Yelon, P.Y. Zavalij, I.V. Saldan, V.K. Pecharsky, J. Alloys Compd. 309 (2000) 75-82.

[15] I.Yu. Zavaliy, R. Cerny, I.V. Koval'chuck, I.V. Saldan, J. Alloys Compd. 360 (2003) 173-182. 